\title{
Interpretacje
}

\section{Niewidoczni świadkowie Zagłady - biedni Polacy patrzą na Polaków}

Justyna Kowalska-Leder

TEKSTY DRUGIE 2018, NR 3, S. 324-335

DOI: 10.18318/td.2018.3.22

W latach 90. Feliks Tych przeanalizował wybrane losowo dzienniki, pamiętniki i wspomnienia poświęcone w całości lub w części okupacji niemieckiej". Łączyło je to, że wyszły spod pióra Polaków, nie tylko przedstawicieli elit intelektualnych, lecz również innych grup społecznych. Autor Długiego cienia Zagłady szukał w nich zapisów reakcji na Holokaust. Okazało się, że zdecydowana większość pozbawiona była nawet wzmianki o Zagładzie lub zawierała bardzo skąpe wtrącenia na ten temat. Jednocześnie w badanym materiale pod względem liczbowym wyróżniały się doniesienia o prześladowaniu Żydów na terenach wiejskich i w małych miasteczkach. „W tym [...] przypadku stosunek do Żydów jest różny, nie ma jednak milczenia o Zagładzie"2 - pisał Tych. Podkreślał zarazem, że nie do rozstrzygnięcia wydaje się

$1 \quad$ F. Tych Świadkowie Shoah. Zagłada Żydów w polskich pamiętnikach i wspomnieniach, w: tegoż Długi cień Zagłady. Szkice historyczne, Żydowski Instytut Historyczny IN-B, Warszawa 1999.

2 Tamże, s. 24.
Justyna Kowalska-

-Leder - kulturoznawczyni, adiunkt w Instytucie Kultury Polskiej UW, gdzie kieruje Zespołem Badań Pamięci o Zagładzie. Obszary jej zainteresowań to: literatura dokumentu osobistego, doświadczenie Holokaustu, stosunki polsko-żydowskie podczas drugiej wojny światowej, a także pamięć o Zagładzie. Ostatnio współautorka i współredaktorka monografii Ślady Holokaustu w imaginarium kultury polskiej (2017). 
kwestia przyczyn nieobecności tematu żydowskiego w większości relacji i wspomnień. Nie sposób dociec, czy chodzi o obojętność, czy o zagłuszenie traumatycznego doświadczenia, czy też o chęć ukrycia jakichś przewin.

Z kolei Jan Grabowski, przygotowując do publikacji fragmenty dzienników, które ukazują warszawskie getto z perspektywy Polaków, zwrócił uwagę na znaczącą dysproporcję między liczbą takich świadectw a dziennikami żydowskimi ${ }^{3}$. Wiązał to przede wszystkim z sytuacją, w jakiej znaleźli się Żydzi. Dla nich prowadzenie dzienników było rodzajem misji, spełnieniem nakazu zaświadczenia o tragedii narodu skazanego na unicestwienie. Tymczasem „imperatyw rejestrowania okupacyjnej codzienności nie był wśród Polaków tak silny jak wśród Żydów"4. Zapewne równie ważnym powodem dysproporcji między dostępnymi dziś świadectwami Żydów i Polaków był sposób traktowania tych materiałów w okresie powojennym. Odpowiedzią na skalę Zagłady było utworzenie zaraz po wojnie instytucji gromadzących dokumenty, które ukazywały jej przebieg i doświadczenia ofiar.

Jan Grabowski przedstawił fragmenty siedmiu dzienników pozostających poza obiegiem czytelniczym ${ }^{5}$. Ich autorzy, od momentu gdy warszawskie getto zostaje otoczone murem, bazują na plotkach i pogłoskach. Sytuacja Żydów nie jest im znana z obserwacji, lecz przez rozmaite, mniej lub bardziej wiarygodne doniesienia. Dopiero podczas powstania w getcie docierają do nich różne oznaki tego, co dzieje się w dzielnicy zamkniętej: widok płomieni czy zapach spalenizny. W przywołanych dziennikach wyraźnie zaznacza się wizualna separacja strony „żydowskiej” i ,aryjskiej”, czego tekstowymi wykładnikami są powtarzające się zwroty: „podobno”, ,jak mówią”, „według innej wersji". Zwracam uwagę na ten proksemiczny wymiar doświadczenia, bowiem w centrum moich analiz sytuuje się dziennik prowadzony na polskiej prowincji, gdzie kontakt z rzeczywistością Zagłady był zupełnie inny.

W dużych miastach, jak Warszawa czy Kraków, mury oddzielające getto od „aryjskiej” strony w znacznej mierze spełniły zamierzoną przez Niemców

3 J. Grabowski Biedni Polacy patrzq na warszawskich Żydów i na getto warszawskie, "Zagłada Żydów. Studia i Materiały" 2014 nr 10, t. 2.

4 Tamże, s. 527.

5 Wybrane i opublikowane przez Jana Grabowskiego fragmenty pochodzą z dzienników następujących osób: pisarki Aurelii Wyleżyńskiej, lekarza Wincentego Sobolewskiego, profesora geografii, przedwojennego dyplomaty i działacza społecznego Stanisława Srokowskiego, pisarki i działaczki społecznej Anieli z Miłkowskich Samotyhowej, adwokata i sędziego Stanisława Wilczyńskiego i etnografa Adama Chętnika, a także Franciszka Wyszyńskiego. Szczegółowe informacje bibliograficzne - Zob. tamże, s. 528-529. 
funkcję separacyjną. Jak pisał Emanuel Ringelblum, przecięły kontakty zawodowe i towarzyskie oraz współpracę polityczną i gospodarczą . Izolacja okazała się nieskuteczna tylko w jednym aspekcie, a mianowicie - w dziedzinie handlu. Wedle szacunków Adama Czerniakowa 80\% żywności dostarczanej do warszawskiego getta pochodziło z przemytu? ${ }^{7}$.Ta wymiana handlowa miała wymiar zarówno detaliczny, jak i hurtowy ${ }^{8}$. Należy jednak pamiętać, że spośród około 400 gett utworzonych na dawnych terenach Polski większość, zwłaszcza na prowincji, nie była odseparowana za pomocą wysokich murów, lecz płotów, parkanów lub drucianych siatek ${ }^{9}$. W wielu przypadkach, jak np. w Łukowie pod Lublinem czy w Szczebrzeszynie na Zamojszczyźnie, teren getta ogrodzony był krótko albo nie był odgrodzony wcale, a wcześniej Żydów obowiązywał zakaz opuszczania wydzielonej im przestrzeni ${ }^{10}$.

Właśnie z Łukowa, położonego w dystrykcie lubelskim Generalnego Gubernatorstwa, pochodzą zapiski przedwojennego nauczyciela szkoły ludowej Stanisława Żemińskiego" ${ }^{11}$. Impulsem do prowadzenia notatek były dla niego

6 E. Ringelblum Stosunki polsko-żydowskie w czasie drugiej wojny światowej, Czytelnik, Warszawa 1988, s. 66 .

7 A. Czerniaków Adama Czerniakowa dziennik getta warszawskiego 6 IX 1939-23 VII 1942, oprac. M. Fuks, PWN, Warszawa 1983, s. 231.

8 Zob. P. Opoczyński Reportaże z warszawskiego getta, przeł. i oprac. M. Polit, Centrum Badań nad Zagładą Żydów - ŻlH, Warszawa 2009; H. Grynberg, J. Kostański Szmuglerzy, Wydawnictwo "Twój Styl", Warszawa 2001; L. Hering Meta, w: tegoż Ślady, Czarna Owca, Warszawa 2011.

9 Hasło "getta w okresie Holokaustu", w: Polski słownik judaistyczny. Dzieje. Kultura. Religia. Ludzie, t. 1, oprac. Z. Borzymińska, R. Żebrowski, Wydawnictwo Prószyński i S-ka, Warszawa 2003.

10 Zob. J. Kowalska-Leder Mur, w: Ślady Holokaustu w imaginarium kultury polskiej, red. P. Dobrosielski, J. Kowalska-Leder, I. Kurz, M. Szpakowska, Wydawnictwo Krytyki Politycznej, Warszawa 2017.

11 Stosuję zapis nazwiska w formie "Żemiński", a więc w takiej, jaka figuruje w maszynopisie jego dziennika w zbiorach Archiwum Żydowskiego Instytutu Historycznego. Zob. AŻıH, 302/30, Dziennik Stanisława Żemińskiego. Alina Skibińska, autorka pierwszego nieocenzurowanego wydania dziennika Żemińskiego, stawia hipotezę, że diarysta był przesiedleńcem z zachodnich ziem Polski wcielonych do Rzeszy w 1939 roku, nie pochodził więc z Łukowa, a jego nazwisko powinno być zapisywane w formie "Rzemiński". Zob. A. Skibińska "Ludzie opowiadali rzeczy potworne o tym, co tam się działo". Dwa świadectwa Zagłady - Adama Ulricha z Zakrzówka i Stanisława Ż(Rz)emińskiego z Łukowa, "Zagłada Żydów. Studia i Materiały” 2018 nr 13, s. 601. Wszystkie cytaty pochodzić będą z tego wydania. W 1958 roku ukazała się ocenzurowana i mocno zniekształcona wersja dziennika Żemińskiego. Zob. S. Żemiński Kartki dziennika nauczyciela wŁukowie zokresu okupacji hitlerowskiej, ,Biuletyn Żydowskiego Instytutu Historycznego" 1858 $\mathrm{nr} 3$. 
- co wyjątkowe - przeżycia świadka Zagłady, która jest jedynym tematem dziennika. Umożliwia on wgląd w jeden z wariantów doświadczenia, które zwykle określane jest jako dominująca w polskim społeczeństwie postawa obojętności wobec Holokaustu. Gdyby bowiem Żemiński stał się bohaterem świadectwa któregoś z mieszkańców łukowskiego getta, z pewnością zostałby opisany jako milczący i obojętny obserwator cierpienia Żydów.

Mimo niewielkiej objętości dziennik Stanisława Żemińskiego jest bardzo cennym świadectwem w Zespole „Pamiętniki” Archiwum Żydowskiego Instytutu Historycznego ${ }^{12}$. Autor podczas wojny pracował jako urzędnik Spółdzielni Spożywców „Społem” i w związku z tym odwiedzał okoliczne sklepy i magazyny. Odnotował więc nie tylko położenie Żydów łukowskich, lecz również to, co działo się w sąsiednich miejscowościach. Prowadził swoje zapiski od 27 października do 16 listopada 1942 roku.

Notatki Żemińskiego, w znacznej mierze poświęcone udziałowi polskiej ludności w mordach na Żydach oraz grabieży ich dobytku, w ostatnich latach zwróciły uwagę badaczy. Do jego świadectwa odwoływali się zarówno Jan Tomasz Gross i Irena Grudzińska-Gross w książce Złote żniwa. Rzecz o tym, co się działo na obrzeżach Zagłady Żydów ${ }^{13}$, jak i Barbara Engelking w pracy Jest taki piękny słoneczny dzień... LosyŻydów szukających ratunku na wsi polskiej 1942-1945 $5^{14}$ oraz Jan Grabowski, autor Judenjagd. Polowanie na Żydów 1942-1945. Studium dziejów pewnego powiatu ${ }^{15}$. Sięgając po zapiski Żemińskiego, badacze zrealizowali cel wyznaczony przez samego diarystę, który pisał: „Daleki jestem od literackości, chcę notować, notować materiał dla przyszłych literatów, dla naukowców"16.

Autorzy przywołanych prac przytaczają fragment dziennika, w którym Żemiński opisał scenę, jaka rozegrała się w spółdzielczym sklepie w okolicach Łukowa: „W dniu 5 listopada [1942] przejeżdżam przez wieś Siedliska. Wstępuję do Spółdzielni. Chłopi kupują kosy. Sklepowa mówi: «przydadzą się wam na dzisiejszą obławę». Pytam, na jaką obławę, «a na Żydów», zapytałem:

$12 \mathrm{AŻIH}, 302 / 30$, Dziennik Stanisława Żemińskiego.

13 J.T. Gross, I. Grudzińska-Gross Złote żniwa. Rzecz o tym, co działo się na obrzeżach ZagładyŻydów, Znak, Kraków 2011.

14 B. Engelking /est taki piękny słoneczny dzień... Losy Żydów szukających ratunku na wsi polskiej 1942-1945, Stowarzyszenie Centrum Badań nad Zagładą Żydów, Warszawa 2011.

15 J. Grabowski Judenjagd. Polowanie na Żydów 1942-1945. Studium dziejów pewnego powiatu, Stowarzyszenie Centrum Badań nad Zagładą Żydów, Warszawa 2011.

16 S. (Ż)(Rz)emiński Pamiętniki. Łuków i okolice - getto..., s. 626. 
«a ile płacą za schwytanego Żyda» - kłopotliwe milczenie - mówię więc dalej, że «za Chrystusa zapłacono 30 srebrników, domagajcie się, żeby i wam tyle płacono». Nikt mi nic nie odpowiedział. Odpowiedź usłyszałem przejeżdżając przez las, w salwach karabinów maszynowych dokonywanej obławy"17.

Przed wojną Żydzi stanowili około połowy mieszkańców Łukowa, których ogólną liczbę szacuje się na 12000 osób ${ }^{18}$. W połowie 1942 roku w mieście przebywało już 12000 Żydów (wśród nich deportowani m.in. z Serocka i Mławy, a nawet ze Słowacji). Jeśli przyjmiemy, że liczba nieżydowskich mieszkańców przypominała stan przedwojenny, będzie to oznaczać, że było ich wówczas dwa razy mniej niż Żydów. Wyznaczenie w miasteczku dzielnicy żydowskiej nastąpiło w maju 1941 roku. Zajmowała ona obszar zamieszkany przed wojną przez ludność żydowską i do 4 listopada 1941 roku można było ją opuszczać. Jak pisze Krzysztof Czubaszek w monografii poświęconej Żydom z Łukowa i okolic, dopiero w połowie września 1942 roku, a więc dwa tygodnie przed tzw. akcją likwidacyjną, getto zostało otoczone murem, który miał uniemożliwiać ucieczkę ${ }^{19}$.

Żemiński szczegółowo odnotowuje wydarzenia, jakie rozegrały się podczas pierwszej „akcji” w Łukowie 5 października 1942 roku. Pisze o spędzaniu Żydów na teren targowiska, wywlekaniu ich z domów i kryjówek, o zabijaniu na miejscu, nie tylko za pomocą broni palnej. Konkluzja tego fragmentu jest następująca: „Dla mnie tragizm powiększało to, że w zbrodni tej pławili się nie tylko sami niemcy i sprowadzeni siepacze ukraińscy czy łotewscy, że brała w tym udział nasza kochana policja, bo wiadomo, że to zwierzęta, ale brali w tym udział Polacy - cywile - na ochotnika, a więc «łapacze»z arbeitsamtu i przygodni amatorzy [wyróż. - J.K.-L.]"20.

Żemiński odnotowuje również to, co usłyszał o wydarzeniach rozgrywających się w okolicy. Wspomina m.in. o dworskim gajowym, który zadenuncjował sześcioro Żydów ukrywających się w lasach nieopodal Burca. „W Kąkolewnicy dowiedziałem się, że za dostarczonego Żyda żywcem lub trupem żandarmeria daje trzy litry wódki. [...] Trudno uwierzyć mi, że aż tak nisko upadliśmy moralnie i przyjmowali [sic!] tak podłe i tak uwłaczające

Tamże, s. 633.

Zob. K. Czubaszek Żydzi Łukowa i okolic, Danmar, Warszawa 2008.

Tamże, s. 159.

S. (Ż)(Rz)emiński Pamiętniki. Łuków i okolice - getto..., s. 630. 
nam nagrody. Czy naprawdę jesteśmy aż takimi bydlakami?"21. Nie tylko ten fragment, ale całościowy wydźwięk świadectwa nauczyciela z Łukowa koresponduje ze spostrzeżeniami Zygmunta Klukowskiego, dyrektora szpitala w Szczebrzeszynie, działacza społecznego, którego dziennik wpisał się w ostatnich latach do kanonu świadectw ukazujących Holokaust z polskiej perspektywy. Obaj diaryści precyzyjnie odróżniają to, co zasłyszeli, od tego, co zobaczyli na własne oczy, mocno podkreślając wizualny aspekt opisywanych wydarzeń. Klukowski pisał 22 października 1942 roku: „W ogóle ludność polska nie zachowywała się poprawnie. Niektórzy brali czynny udział w tropieniu i wynajdywaniu Żydów. Wskazywali, gdzie są ukryci Żydzi, chłopcy uganiali się nawet za małymi dziećmi żydowskimi, które policjanci z a b ij a li na oczach w szy s tki ch [wyróż. - J.K.-L.]"22. Klukowski szacuje, że dzień wcześniej wywieziono ze Szczebrzeszyna niemal 1000 Żydów, a na miejscu - w domach, na ulicach, na kirkucie - zabito ich ponad dwukrotnie więcej.

W latach 8o. Jan Tomasz Gross, odwołując się właśnie do dziennika Zygmunta Klukowskiego, pisał: „tzw. stosunki polsko-żydowskie podczas okupacji to nie jest temat do dyskusji w odniesieniu jedynie do marginesów polskiego społeczeństwa - szmalcowników i bohaterów; [...] dokładnie na odwrót, los żydowskich współobywateli tkwi w centrum doświadczenia okupacyjnego polskich mieszkańców każdej miejscowości"23. Dodajmy, że w takim natężeniu, jakie ukazują Klukowski i Żemiński, dotyczyło to przede wszystkim mniejszych miasteczek, szczególnie na wschodzie i w centrum Generalnego Gubernatorstwa.

Społeczne uświadomienie sobie owej „naoczności” Holokaustu oraz różnych form udziału Polaków w Zagładzie do dziś spotyka się z silną blokadą. Mechanizm ten poddali analizie autorzy tekstu Przechwycenie dokumentu: „Po-lin" Jolanty Dylewskiej (2008) ${ }^{\mathbf{2 4}}$. Film przywołuje przedwojenny obraz kilku miasteczek, m.in. znajdującego się aktualnie na Białorusi Skidla (w II RP zamieszkanego w 80\% przez Żydów), Kałuszyna, położonego nieopodal Miń-

21 Tamże, s. 636.

22 Z. Klukowski Zamojszczyzna 1918-1943, Ośrodek Karta, Warszawa 2008, s. 304.

23 J.T. Gross „Ten jest z ojczyzny mojej...", ale go nie lubię, w: tegoż Upiorna dekada. Trzy eseje o stereotypach na tematŻydów, Polaków, Niemców i komunistów 1939-1948, Universitas, Kraków 2001, s. 59. Pierwodruk: J.T. Gross „Ten jest z ojczyzny mojej...", ale go nie lubię, "Aneks” 1986 nr 41-42.

24 E. Janicka, T. Żukowski Przechwycenie dokumentu: „Po-lin” Jolanty Dylewskiej (2008), w: tychże Przemoc filosemicka? Nowe polskie narracje o Żydach po roku 2000, Wydawnictwo IBL PAN, Warszawa 2016. 
ska Mazowieckiego (w II RP 70\% Żydów) czy Kolbuszowej na Podkarpaciu (6o\% Żydów). Jak zauważają Elżbieta Janicka i Tomasz Żukowski, film ukazuje przedwojenną idyllę polsko-żydowską, natomiast czas wojny i Zagłady jako moment gwałtownej dematerializacji Żydów, którzy nie wiadomo jak i kiedy zniknęli z pejzażu prowincjonalnej Polski. Zapiski Żemińskiego pokazują,jak ta dematerializacja wyglądała w rzeczywistości. Warto przy tym podkreślić, że im bliżej końca dziennika, tym więcej miejsca zajmuje w nim opis emocji świadka. 16 listopada 1942 roku w następujący sposób relacjonuje on wydarzenia, które rozegrały się kilka dni wcześniej ${ }^{25}$ : „Dzień odprowadzenia ostatniego transportu Żydów w Łukowie był dla nas (dla mnie i dla mojej żony) najtragiczniejszym dniem naszego życia. Gdy pędzono moją ulicą (11 listopada) ${ }^{\mathbf{2 6}}$ wielotysięczny tłum Żydów, pracowałem w ogrodzie. Gdy czoło kolumny znalazło się przy naszym domu, jakaś tajemnicza siła wyrwała mi rydel z rąk, przyprowadziła tuż do płotu, zdjąłem czapkę, patrzyłem, chcąc wziąć w siebie cały ból, całą rozpacz tego całego tłumu, tych tysięcy ludzi, tych dzieci i matek, tych starców i tej młodzieży. Pytałem, czy jest jakaś wyższa sprawiedliwość, czy jest jakiś Bóg, i mówiłem, że gdy jest Bóg, to musi być draniem nie mniejszym od niemców, to jest zbrodniarzem, gdy zezwala na istnienie takich zbrodni. Gdy pochód przeszedł, nie miałem siły ruszyć się z miejsca. W domu żona moja dostała ataku szału, drąc włosy z rozpaczy. Musiałem sprężyć całą wolę, aby móc [ją] jakoś uspokoić. Przez długie, długie dni nie mogliśmy się uspokoić, człowiek nie jadł, nie spał, a każda praca wypadała z rąk. Myśli otępiały. Ogarnął nas paniczny strach. Uciekłem z Łukowa i przez parę dni leżałem chory - rozstrój nerwowy. Co zresztą pisać o tym, gdy człowiek nie znajduje słów mogących wyrazić miotające nami uczucia"27.

Dziennik Żemińskiego ukazuje jedną z postaw tzw. świadków Zagłady, którą poznajemy tylko dlatego, że prowincjonalny nauczyciel i urzędnik, dobrze zaznajomiony z praktykami piśmiennymi, poczuł wewnętrzny przymus prowadzenia zapisków. Na poziomie behawioralnym, dającym się zaobserwować przez otoczenie, małżeństwo Żemińskich, prezentuje postawę obojętną. Zapiski ujawniają jednak stan przeżyć będący zaprzeczeniem obojętności. Mamy tu do czynienia z silnym zaangażowaniem emocjonalnym, a także

25 Pierwsza deportacja Żydów z Łukowa trwała od 5 do 8 października, druga przypadła na 28 października 1942 roku.

26 Diarysta najwyraźniej pomylił datę. Chodzi o wydarzenia z 7 listopada 1942 roku. Zob. K. Czubaszek Żydzi Łukowa i okolic..., s. 167.

27 S. Ż(Rz)emiński Pamiętniki. Łuków i okolice - getto..., s. 638. 
z pewną formą działania, bowiem właśnie wtedy, pod wpływem widoku scen skrajnej przemocy Żemiński zaczyna prowadzić dziennik. Tym samym zmienia swój status - przekształca się z obserwatora w świadka.

Postać Stanisława Żemińskiego, obserwującego Żydów brutalnie zapędzanych do transportu, wywołuje skojarzenie z figurą „biednego Polaka patrzącego na getto". Do polskiego imaginarium wprowadził ją - jak wiadomo - w 1987 roku Jan Błoński ${ }^{28}$. Pisał on o winie wynikającej z samego faktu bycia świadkiem przestępstwa: „Można być współ-winnym, nie biorąc udziału w zbrodni. Najpierw poprzez zaniechanie czy przeciwdziałanie niedostateczne"29. W eseju jest również mowa o przedwojennym antysemityzmie, który na szczęście podczas wojny miał nie przełożyć się na czyny („Bóg tę rękę zatrzy$\mathrm{mal}^{\text {"30}}$ ). Jednak to właśnie na jego podglebiu - zdaniem Błońskiego - wyrosła obojętność wobec Żydów, będąca konsekwencją tego, że długo przed wojną zostali wyłączeni ze wspólnoty międzyludzkich i obywatelskich zobowiązań. To z tego miejsca wypływa źródło „współ-winy” Polaków.

Nie jest moją intencją ponowne wskrzeszenie w debacie o relacjach polsko-żydowskich figury „biednego Polaka patrzącego na getto”. Po ukazaniu się Sąsiadó $w^{31}$ Grossa i wielu późniejszych publikacji taki rodzaj reanimacji byłby i nieuczciwy, i niemożliwy, już choćby w kontekście dziennika Żemińskiego, który tyle uwagi poświęca czynnemu zaangażowaniu Polaków w Zagładę. W ten sposób uniemożliwia również ekstrapolację własnego, niewątpliwie traumatycznego doświadczenia, na polskie społeczeństwo. Jak sam pisze: „Polaków jest dużo i reakcji jest wiele. O draństwach dosyć dużo piszę. Jest dużo ludzi, którzy potępiają zbrodnie niemieckie i brzydzą się nimi. Są ludzie, którzy na widok wyczynów niemieckich dostają szału rozpaczy. Najpowszechniejsze jednak zdanie Polaków jest takie: «przykre i okrutne to, lecz tu niemcy oddają nam dużą przysługę: rozwiązują problem żydowski». Nasza endecja ze wszystkimi swoimi przybudówkami może być dumna ze swego posiewu. Kościół rzymskokatolicki nareszcie święci swój tryumf. Winszuję 2-ch tysiącleci!"32.

28 J. Błoński Biedni Polacy patrzq na getto, "Tygodnik Powszechny” 1987 nr 2.

29 J. Błoński Biedni Polacy patrzą na getto, w: tegoż Biedni Polacy patrzą na getto, Wydawnictwo Literackie, Kraków 2008, s. 30-31.

Tamże, s. 33 .

J.T. Gross Sąsiedzi. Historia zagłady żydowskiego miasteczka, Pogranicze, Sejny 2000. 
Artykuł Elżbiety Janickiej Pamięć przyswojona. Koncepcja polskiego doświadczenia zagładyŻydów jako traumy zbiorowejw świetle rewizji kategorii świadka ${ }^{33}$ stanowi gruntowną krytykę wizji Holokaustu jako doświadczenia granicznego Polaków. Fundamentem przeprowadzonego tam rozumowania jest założenie, że w odniesieniu do kultury polskiej, rozpatrując wpisane w nią wyobrażenia, wartości i praktyki, mówić należy o kulturze antysemickiej: ,antysemityzm nie stanowi jedynie jednego z nurtów czy kodów owej kultury, lecz jest generatorem tożsamości wspólnoty - najpierw religijnej, następnie narodowej, ustanawianej według kryteriów etniczno-religijnych - będącej również wspólnotą aksjonormatywną"34. W stosunku do Żydów w polskim społeczeństwie nie nastąpiła istotna zmiana po doświadczeniu Zagłady. Tak więc - jak twierdzi Janicka - nie było ono dla Polaków zbiorową traumą. Zgadzając się z zasadniczą konstatacją autorki, dotyczącą funkcji, jakie w kulturze polskiej pełni antysemityzm, nie możemy jednak przeoczyć tego, że Zagłada była dla wielu Polaków doświadczeniem uświadomienia sobie prawdziwości tej właśnie konstatacji. Tacy świadkowie, jak Żemiński czy Klukowski, uzyskali głęboki, a jednocześnie bolesny wgląd w istotę zbiorowego fantazmatu. Jednak ze względu na ekstremalnie przemocowy charakter opisywanych przez nich wydarzeń cała nasza uwaga skupia się na tym, co relacjonowane. Odnotowane zdarzenia przesłaniają to, co znaczyły dla relacjonujących, powodując, że stają się oni niemal niewidoczni. Z taką sytuacją mamy do czynienia również w przypadku późnego świadectwa złożonego przez Tadeusza Markiela, który jako dwunastoletni chłopiec był świadkiem tortur, jakim we wsi Gniewczyna pod Przeworskiem w 1942 roku polscy mieszkańcy poddali dwie żydowskie rodziny, Adlerów i Trynczerów, a następnie oddali je w ręce żandarmów ${ }^{35}$.

Pisząc o Polakach biorących udział w Holokauście, Barbara Engelking nazywa ich wolontariuszami Zagłady, którzy „poza nielicznymi wyjątkami - na pewno nie byli przymuszani do aktywnego czynienia zła; nie musieli

33 E. Janicka Pamięć przyswojona. Koncepcja polskiego doświadczenia zagłady Żydów jako traumy zbiorowej w świetle rewizji kategorii świadka, "Studia Litteraria et Historica” $2015 \mathrm{nr}$ 3/4, https:// ispan.waw.pl/journals/index.php/slh/article/view/slh.2015.009 (12.02.2018).

Tamże, s. 166.

35 T. Markiel Zagłada domu Trinczerów, "Znak” 2008 nr 4. Uzupełniona przez autora relacja wraz z rozbudowanym komentarzem historycznym została opublikowana trzy lata później. Zob. T. Markiel, A. Skibińska "Jakie to ma znaczenie, czy zrobili to z chciwości?". Zagłada domu Trynczerów, Stowarzyszenie Centrum Badań nad Zagładą Żydów, Warszawa 2011. 
wydawać ani mordować Żydów"36. Badając motywację dobrowolnych uczestników nagonek i mordów, autorka wskazuje na chciwość, zazdrość, nienawiść, a nawet nudę. Wyodrębnia też kategorię polskich ochotników, których motywacji nie sposób dociec. Wydają się oni wolontariuszami najwyższej miary pośród pozostałych ochotników. Można powiedzieć, że działają automatycznie - afektywnie zaprogramowani przez wzór kultury antysemickiej. Podobnie jak anonimowa przeciętna Polka, opisana przez Jarosława Marka Rymkiewicza w Umschlagplatz ${ }^{37}$, która na widok dziecka przekradającego się z warszawskiego getta na aryjską stronę zaczyna przeraźliwie krzyczeć „Jude!”. Zachowanie kobiety przypomina odruch, będący skutkiem długotrwałego warunkowania. To bezrefleksyjna, spontaniczna, psychofizyczna reakcja na bodziec. Można ją zaobserwować we wszystkich środowiskach i kręgach zawodowych, również wśród wybitnych polskich intelektualistów, którym daleko do poglądów endeckich.

Maria Dąbrowska, autorytet liberalnej i lewicowej inteligencji, w swoim dzienniku w maju 1944 roku pisała: „Jezus Maria. Jak ja drżę, że zwycięstwo bolszewicko-angielskie mogłoby oddać znowu Polskę w ręce Żydów. Na myśl, że nasze miasteczka mogłyby znów zamrowić się tym posępnym czarnym tłumem - wszystko nam z rąk wydzierającym - zimny dreszcz mnie przechodzi i żyć się nie chce"38. Cytowany fragment ukazał się dopiero czterdzieści lat po śmierci pisarki, w pierwszym pełnym wydaniu jej dziennika. Przypomnijmy, że mowa o autorce słynnego artykułu Doroczny wstyd z 1936 roku, w którym oskarżyła całe polskie społeczeństwo o winę za antysemicką przemoc na uniwersytetach.

Z podobną sytuacją spotykamy się w przypadku pisanego we Francji podczas wojny dziennika Andrzeja Bobkowskiego. Jego opublikowane w 1957

B. Engelking Jest taki piękny słoneczny dzień... Losy Żydów szukających ratunku na wsi polskiej $1942-1945 \ldots$, S. 155.

J.M. Rymkiewicz Umschlagplatz, Instytut Literacki, Paryż 1988.

Cyt. za: T. Drewnowski Węzły nierozsupłane. Maria Dąbrowska i Żydzi, "Fakt” 2006 nr 13 (dodatek kulturalny „Europa”). Fragment został pominięty w wydaniu dzienników z 1988 roku. Por. M. Dąbrowska Dzienniki, t. 2, oprac. T. Drewnowski, Czytelnik, Warszawa 1988, s. 434435. Cytowane słowa zostały opublikowane w pierwszym całościowym wydaniu Dzienników Dąbrowskiej, które ukazało się zgodnie z wolą autorki dopiero czterdzieści lat po jej śmierci. Trzynastotomowa edycja dostępna jest jedynie wąskiemu gronu badaczy - nakład wyniósłbowiem 300 egzemplarzy i stanowi transkrypcję notatek, pozbawioną aparatu krytycznego. Zob. M. Dąbrowska Dzienniki 1914-1965, wyd. pod kier. T. Drewnowskiego, Polska Akademia Nauk, Warszawa 2009. 
roku w Paryżu Szkice piórkiem to manifest nonkonformizmu i krytycznego dystansu wobec polskiego narcyzmu oraz narodowego patosu. Jest to apoteoza wolności jednostki i ostra krytyka patriotycznych automatyzmów. „Polska usiadła nam na mózgach i paraliżuje myślenie. Zamiast być «homo sapiens», należymy do rasy «homo polacus», do rasy ogłupionej ojczyzną, do kretynów chorobliwego patriotyzmu i nacjonalizmu"39 - pisał Bobkowski w lipcu 1943 roku. Odkryty w 2008 roku rękopis jego dziennika przyniósł szereg zaskoczeń, wśród których niewątpliwe największe wynikło z odkrycia żywego, by nie powiedzieć - żywiołowego antysemityzmu, niepasującego do wizerunku „kosmopolaka” - jak lubił się sam określać. Tymczasem okazało się, że Bobkowski, przygotowując swoje zapiski do publikacji w wydawnictwie Jerzego Giedroycia, nie tylko skrupulatnie usunął wrogie Żydom fragmenty (wraz z cytatami z Protokołów Mędrców Syjonu), lecz także wstawił w kilku miejscach wyrazy empatii dla ofiar Zagłady i słowa podziwu dla roli,jaką Żydzi odegrali w kształtowaniu się kultury europejskiej ${ }^{40}$.

Lektura ocenzurowanych przez Bobkowskiego i Dąbrowską fragmentów ich dzienników to dla wielu czytelników rodzaj wstrząsu, gwałtownego rozpoznania, będącego jakby namiastką doświadczenia takich świadków Zagłady jak Żemiński, Klukowski czy Markiel. Polski antysemityzm, zarówno przed wojną, jak i dziś, postrzegany zazwyczaj jako zjawisko marginalne - odsłania się jako podglebie kultury polskiej. Jest rodzajem przesądu, nie zawsze artykułowanego, ale jednak głęboko uwewnętrznionego przez jej uczestników i współtwórców. Dlatego nawet jeśli Zagłada dla wielu (nie wiadomo, jak wielu) polskich świadków była traumą, to ich doświadczenie nie mogło zburzyć wspornika tożsamości zbiorowej Polaków. Przedsądy - co prawda zwykle będące fikcją - konstytuują rzeczywistość społeczną. Gdyby je usunąć, nie miałaby się, na czym oprzeć. 


\section{Abstract}

\section{Justyna Kowalska-Leder}

UNIVERSITY OF WARSAW

Invisible Witnesses of the Holocaust

Holocaust witnesses recognized the scale of Polish society's hostility towards Jews. It was especially evident in the countryside, where violent acts were committed not behind ghetto walls but in the streets and at Jewish cemeteries. Kowalska-Leder examines testimonies by Stanisław Żemiński, Zygmunt Klukowski and Tadeusz Markiel, which thematize the Poles' participation in the Holocaust - an image that continues to have traumatic potential. Anti-Semitic tendencies are deeply rooted in Polish culture. This is apparent not only in popular attitudes in the countryside but also in statements by outstanding intellectuals such as Maria Dąbrowska or Andrzej Bobkowski. Recently published passages from their diaries testify to their hostility towards Jews and their lack of empathy towards the victims of the Holocaust.

\section{Keywords}

witness, Holocaust, Polish-Jewish relations, complicity in the Holocaust, anti-Semitism, Polish occupation diaries 